\title{
DES MOINES RIVER NAVIGATION; GREAT EXPECTATIONS UNFULFILLED
}

\section{By Dave Hubler}

As the American frontier crossed the Mississippi River, settlers in the Wisconsin Territory became increasingly concerned with means of transportation. Nearing the Great Plains, one encountered fewer streams that would carry civilization, as they had in the old Northwest Territory. The arrival of the railroad uas 25 years away, but no one knew that. What few large rivers there were, were examined for their potential as arteries of commerce. One such was the Des Moines River, which led to the interior of lowa, and which many thought was the "gateway to the West."

People that settled on the banks of rivers looked to the future with great expectations. Where ever three or four buildings were gathered at a fork, prophets saw their particular site mushrooming into the "new" Pittsburg, or St. Louis. Very feiv of these dreams ever paid any dividends and one of the best examples is that of plans to make the Des Moines River fit for navigation.

This paper seeks to show some of the hopes and folly that grip men when prosperity and boom are forecast in "just the very near future."

Between the Mississippi and Missouri Rivers lies a fertile plain, 300 to 400 miles wide. The Des Moines River rises in the northern sector of this plain, at the highest altitude of any Iowa tributary of the Mississippi. It flows from Minnesota into Iowa and crosses the state in a southeasterly direction, joining the Father of Waters in the corner of the state at Keokuk. It is the only river which completely crosses the state from its northern boundary to its southern boundary. ${ }^{1}$ It was the first river in Iowa to be navigated by steamboats; it carried the largest and most sustained tonnage, and it was navigated to a greater extent than any other river in the state. Because of its geographical location and the

1 See Map "The Des Moines River Valley." 
geological effects of glacial movements, Iowa did not furnish broad, navigable streams upon which civilization could move easily and swiftly. The only exceptions to this were the Mississippi, the Missouri, the Iowa, and the Des Moines Rivers. ${ }^{2}$

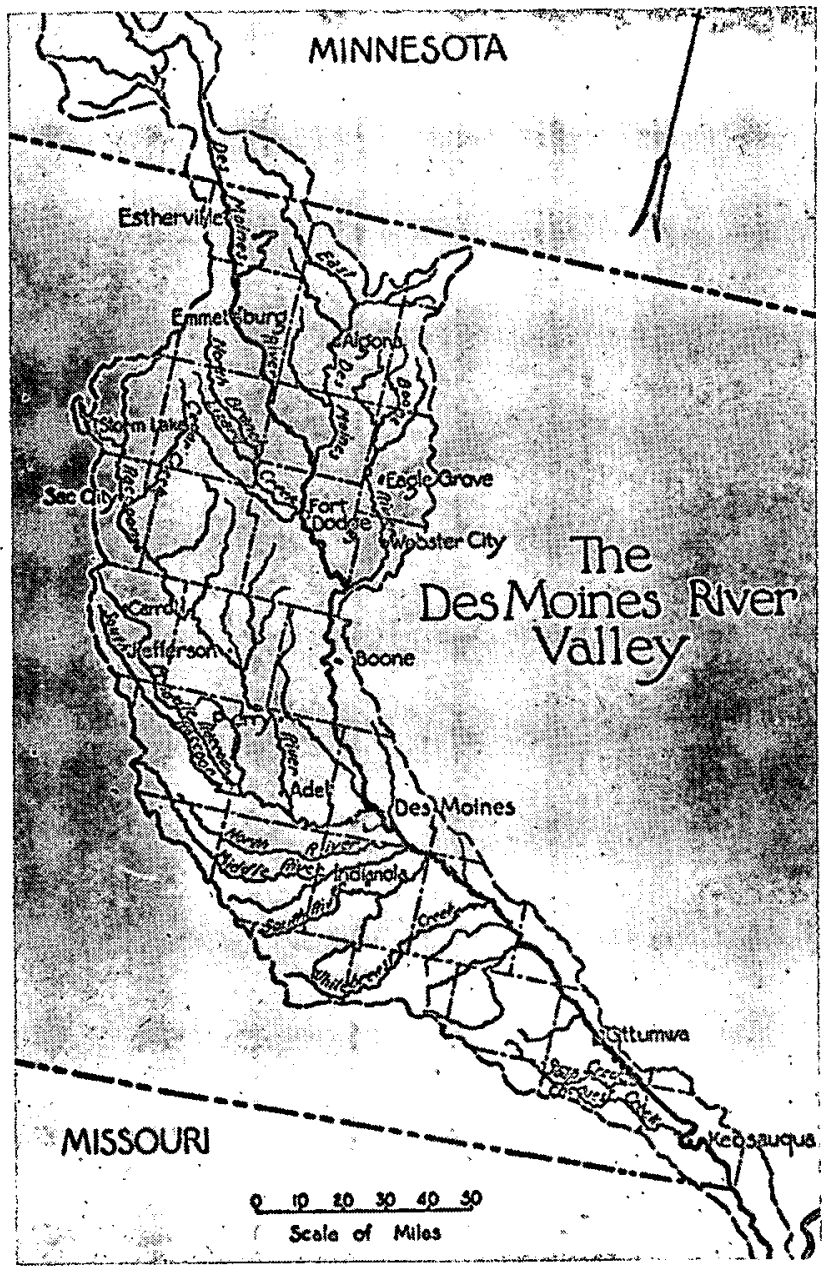

Map Furnisbed by autbor 11

Map of Des Moines River Valley

${ }^{2}$ Remley J. Glass, "Early Transportation and the Plank Road," Anials of Iowa, XXI (January, 1939), p. 503. 
During the summer of 1835, Lt. Col. Stephen Kearney dispatched Lt. Albert M. Lea of the First United States Dragoons down the Des Moines to determine the practicability of its navigation. ${ }^{3}$ Lea's reports were quite enthusiastic. $\mathrm{He}$ described the stream as "from 150 to 250 yards [wide] except a few miles about the mouth, where it is only from 80 to 100 yards wide." Lea ended his report by declaring "there is no obstruction to the navigation of the Des Moines in a tolerable stage of water." ${ }^{4}$

After the Black Hawk War, thousands of settlers had illegally crossed into this Indian territory and finally gained some autonomy by being admitted to the Union as a territory in 1838. Most of the people settled along the rivers and streams, avoiding the equally good or better farmland in the intervening prairies. Failing to realize that the forest did not mark the richest soils, "they based their appraisal of any new land's fertility upon the number and size of the trees." The census of 1836 showed 10,531 people in Iova and when the territory became a state ten years later, the population had doubled to $22,859 .{ }^{\circ}$ Van Buren County's number of inhabitants stood at 3,174 at the time of statehood. ${ }^{7}$

John Plumbe, an early settler of Iowa took special note of the development of the Des Moines Valley and saw a great future for its growth. He called it a "fine river" and predicted the Des Moines would be "navigated by steam boats for all the purposes of trade a great distance from its

3 Jacob Van der Zee, "The Opening of the Des Moines Valley," Iowa Journal of History and Politics, XIV (October, 1916), p. 488.

${ }^{4}$ Albert M. Lea, Notes on the Wisconsin Territory Particularly with Reference to The Iowa District or Black Hawk Purchase (Philadelphia: H. S. Tanner, 1836), p. 24.

${ }_{5}$ James H. Lees, "Physical Features and Ceologic History of Des Moines Valley," Iowa Geological Survey, Vol. XXV, Annual Report, 1914 (Des Moines: Robert Henderson, State Printer, 1916), p. 430; and Dale Van Every, The Final Challenge: The American Frontier 1804-1845 (New York: William Morrow and Company, 1964), pp.
311-312.

' Iowa: The Home for Immigrants, Being a Treatise on the Resources of Iowa (Des Moines: Mills \& Co., Printers and Publishers, 1870), p. 13.

7 A. T. Andrea's Illustrated Historical Atlas of the State of Iowa (Chicago: Lakeside Press, 1875), p. 412. 
month." Commenting on the influx of settlers, Plumbe said the

country watered by the Des Moines is by far the most densely settled of Iowa. From its mouth for forty or fifty miles upwards, there is a constant succession of towns ...

It is apparent, therefore, that a very few years will elapse, ere its trade will be an object worthy the highest attention. ${ }^{9}$

Actual transportation on the river during this period seems to have consisted only of keel-boats and canoes until 1837. In September of that year, the steamboat Science, commanded by S. B. Clark, brought a load of goods up the river to Keosauqua in Van Buren County. Soon thereafter, the American Fur Company, which had a post at the fork of the Des Moines and Raccoon Rivers (present site of the city of Des Moines) began to have their supplies shipped in by small steamboats. ${ }^{10}$ This activity led to increased population along the river. Van Buren County doubled its inhabitants from 1838 to 1840 while the state was also jumping from 22,859 to 43,114. ${ }^{11}$ Maps now listed several flourishing towns on the banks of the stream such as St. Francisville, Farmington, Van Buren, Rochester, Lexington, Bentonsport, and many others. ${ }^{12}$

\section{River Surveys}

This concentration of people prompted the government to conduct further surveys of the river. Two were completed, one by Capt. W. Bowling Guion in the spring of 1841, and the other by Lt. John C. Fremont in July of the same year. Guion reported "the practicability of its navigation is placed beyond a doubt,"13 and Fremont wrote

s John Plumbe Jr., Sketches of Iowa and Wisconsin, Embodying the Experience of a Resillence of Three Years in those Territories (St. Louis: Chambers, Harris \& Knapp, 1839), p. 36.

9 Ibid., p. 57.

10 Van der Zee, “The Opening," p. 553; and William J. Petersen, Iowa: The Rivers of Her Valleys (Iowa City: State Historical Society of Iowa, 1941), p. 186.

11 Andrea's Atlas, p. 412; and Iowa: The Home, p. 13.

12 Isaac Galland, Galland's Iowa Emigrant: Containing a Map, and General Descriptions of Iowa Territory (Chillicothe, Ohio: Wm. C. Jones, 1840), p. 8.

${ }_{13}$ "Early Reports Concerning the Des Moines River," Iowa Journal of History and Politics, XVI (January, 1918), p. 111. 
"that this river is highly susceptible of improvement, presenting nowhere any obstacles that would not yield readily, and at slight expense."14

For those already settled in the valley, these investigations may have seemed quite worthless because they were not immediately followed up by actual improvements or projects. There were no railroads here, and none in the foreseeable future, and the people of the frontier knew their only hope lay in the improvement of waterways at government expense. ${ }^{15}$ One needs only look at an early atlas of Western America to see how closely water transportation was connected to settlements. A map prior to 1850 shows Keosauque, Ottumwa, and Ft. Des Moines on the Des Moines River, with other towns on the Iowa, Wapsipinicon and Turkey Rivers. But almost no other interior settlements appear.

The city of Ottumwa was staked out and born May 2, 1843, on the banks of the Des Moines. ${ }^{16}$ That same week, the steamer Ione, with a detachment of soldiers aboard, reached Des Moines, ${ }^{17}$ and from that time on, every Des Moines River town pictured itself as an "incipient St. Louis," and knew that it had to attract for itself settlers for the back country. ${ }^{18}$

Eastern journalists became quite conscious of these budding cities in the West. One wrote about the new county seat of Wapello County (Ottumwa) and "supposed that there [were] about 5,000 inhabitants in that county." $\mathrm{He}$ went on to ask, "Where is the new purchase?" and then answered with, "Why reader, it is somewhere near the heads of the Des Moines river [sic]," where the editor envisioned "piles of ice and banks of snow just finishing their melting," in June. ${ }^{19}$

Other newspapers also found events newsworthly in the development of the Territory. The St. Louis New Era reported

14 Ibid., p. 118.

15 Van der Zee, "The Opening," p. 557.

18 Tacitus Hussey, Beginnings: Reminiscences of Early Des Moines (Des Moines: American Lithographing and Trg. Co., 1919), p. 116.

${ }_{17} \mathrm{H}$. B. Turrill, Historical Reminiscences of the City of Des Moines, Iowa (Des Moines: Redhead \& Dawson, 1857), p. I.

18 Glass, p. 508.

19 Niles National Register, LXIV (June 15, 1843), p. 311. 
in 1844 that a steamboat named Iola under a Captain Devinney of Fort Raccoon carried machinery up the river for a new sawmill at Keosauqua. This was "hailed at Keosauqua .. . as the harbinger of wealth and prosperity to that country."20

Even Washington became aware of these new developments in the Des Moines Valley. Augustus Caesar Dodge, the Territorial delegate to Congress, informed the solons of the possibilities of the Territory. Stressing the fertility and increasing population, he went on to campaign for a new location for the capital. "From the central position this river," he said, "and its other advantages, there are a very large proportion of the people of Iowa who believe, and desire, their ultimate seat of Government should be upon it." ${ }^{\text {"1 }}$ The census of 1847 seemed to support Dodge's contention. The total population of Iowa had again doubled since 1842 , and now stood at 116,454. These settlers were distributed over 32 counties, although concentrated in the southeast. Des Moines (Burlington), Lee (Keokuk), and Van Buren Counties were the only three boasting more than 10,000 inhabitants, while Dallas County, at the Raccoon Fork, could muster only 164 white inhabitants. ${ }^{22}$.

With the population increasing at such a high rate, it was imperative that better transportation facilities be provided. And, the most feasible project was the conversion of the Des Moines River into a commercial waterway. Means to accomplish this were asked by a bill introduced by A. C. Dodge. By an act of Congress on Aug. 8, 1846, a grant of land was given to the Territory of Iowa "to aid in the improvement" of navigation on the Des Moines River. ${ }^{23}$ Most readers failed to notice that the act did not guarantee navigability.

The grant consisted of all odd-numbered sections on either side of, and within five miles of the river. No one

20 "Navigation of the Des Moines," Annals of Iowa XXIX (July, 1947) p. 63 .

21 Van dee Zee, “The Opening," p. 557.

22 Glass, p. 507; and Andrea's Atlas, p. 412.

${ }^{23}$ Appendix to the Congressional Globe, Vol. XLII, No. 1, 41st Cong., 2nd Sess. (February 1, 1870), p. 421. 
was quite sure if this meant to the Raccoon Fork or to the upper boundary of the Territory, or to the source of the river, somewhere in Minnesota. ${ }^{24}$ Four months after the grant, Iowa was admitted to the Union as a state and on January 9 of the next year, the Iowa Legislature accepted the grant. Men now began to calculate the eventual returns of this vast area. With an estimated 400,000 acres below the Raccoon Fork and another 560,000 acres above the Fork, legislators foresaw an income of $\$ 1,200,000$ if sold at a minimum $\$ 1.25$ per acre. When many realized the financial implications and scope of the grant, they began to speculate as to the true meaning of the act, and to debate the real northern extent of the grant. ${ }^{25}$ This was now a political question and in February of 1847, the Legislature created a Board of Public Works to administer the grant and provide for the improvement of the river. ${ }^{26}$ Newspapers and political parties now began to form and endorse slates of candidates for the Board of Public Works which would support improvement of the Des Moines River. ${ }^{27}$

Sale of land in the grant proceeded, and the first contracts for construction of locks and dams were let in June of 1848. These provided for the first 35 miles of the river; from the mouth at Keokuk up to Farmington which was about 11 miles below the Big Bend. These contracts included three dams and two locks which were to cost from $\$ 20,000-\$ 30,000$ a piece. ${ }^{28}$ This was followed in August by the second group of contracts to bring the improvements as far up river as Ottumwa. ${ }^{28}$ This activity contributed to the "fervent belief ... that it was entirely feasible by dams and locks to make the river a great and permanent artery of trade, [and] the chief dependence of the state in the teeming commerce

24 Lea, p. 276.

25 Ibid., p. 277.

${ }^{26}$ The History of Van Buren County, Iowa, containing A History of the County, its Cities, Towns, Etc. (Chicago: Western Historical Company), pp. 206-207; and Acts and Resolutions of the First General Assembly of the State of Iowa (Iowa City: State Printer, 1847), pp. $165-170$.

27 The Des Moines Valley Whig (Ottumwa), July 16, 1847.

${ }^{28}$ Ibid., June 9, 1848.

${ }^{20}$ Ibid., September 1, 1848 
certain to follow its rapid development already under way." Few imagined, in 1846, that this grant was to be almost totally ineffective; "an idle dream to be rudely shattered by the coming of the Iron Horse." 31

The Board of Public Works went to work immediately after its election. Col. Samuel R. Curtis, a former Army engineer from Ohio, was hired as chief engineer of the improvement project. Having served in the same capacity for the slack-water improvement of the Muskingum River in Ohio, the Board deemed him quite capable. ${ }^{32}$ Curtis conducted a complete new survey and found the distance from the mouth of the river to the Raccoon Fork was slightly over 204 miles. $^{33}$ The slope of the river was determined to be 1.7 feet per mile so that the site of Fort Des Moines was 310 feet higher than the confluence of the Des Moines and the Mississippi. ${ }^{34}$ The original plan called for 28 dams and locks, but when the project was finally abandoned, only those at Ottumwa, Bentonsport, Keosauqua, Bonaparte, Farmington, and Croton were completed in their entirety. ${ }^{35}$

All of this building, most of which was still on paper, heightened the expectations of the Valley inhabitants. The population of the state was now 191,982 and Van Buren County reported $12,269 .{ }^{36}$ The first Bienniel Report of the Board of Public Works did nothing to dampen the hope of any Iowan. The recent survey disclosed deposits of hydraulic lime, coal, and gypsum along the banks of the river. These alone, said the report, justified the "most strenous exertion to push forward the great improvement in ques-

so James B. Weaver, "The Story of 'The Des Moines River Lands'," Annals of Iowa, XVIII (October, 1932), p. 420.

31 Ibid.

32 Des Moines River, Iowa. Letter From the Secretary of War Transmitting, with a Letter From the Acting Chief of Engineers, Reports on Examination and Survey of Des Moines River, Iowa. House of Representatives Document No. 1063, 62nd Cong., 3rd Sess., 1912, p. 20.

${ }^{33}$ Jacob A. Swisher, "A Plan That Failed," The Palimpsest, XVI (September, 1935), pp. 279-280.

${ }_{34}$ Des Moines River, Iowa, Letter, p. 11.

35 Ibid.

${ }^{36}$ Iowa: The Home, p. 13; and Andrea's Atlas, p. 412. 
tion." ${ }^{37}$ Even the supposedly responsible members of the Board let their visions of prosperity carry them to some quite tenuous conjectures:

Mills and manufactories are necessary to sustain and support the growth and prosperity of the State. This river, when improved as commence, by locks and dams, will not only afford a constant navigation, but an inexhaustible water power. The country offers unrivalled advantages for manufactories. Cotton can be brought here cheaper than to the Merrimac, whilst the fruits of our own rich prairies, wood lands, and the minerals of the hills, among which the Des Moines meanders, would afford employment for thousands of work shops, mills and manufactories. ${ }^{38}$

The engineer's report to the Board estimated the cost of the project would be $\$ 9,344$ per mile, including the ten mile canal at Keokuk. This would amount to four or five times the income expected from the sale of lands because of the loss of expected revenue, ${ }^{30}$ due to an 1848 ruling by the Federal Government. The ruling found the northern extent of the grant to reach no higher than the Raccoon Fork. $^{40}$ Attempting to allay the fears of the Board, Curtis reassured them that a "good railroad through any portion of our State, [would] cost about twice as much . . ."11

Curtis attempted to explain the all-to-frequent work stoppages which already plagued the project. The "extraordinary and destructive freshets" of the winter and spring of 1849 had caused a tremendous flood on the river. This, added to outbreaks of cholera, "occasioned much loss and vexatious delay to the contractors."

Businessmen of the Valley were not to be disturbed by these momentary disturbances. A St. Louis wholesale grocery house anticipated a boom on the Des Moines and proposed to buy a steamer to convey goods from Keokuk to $\mathrm{Ft}$. Des Moines on a regular schedule. Commenting on this decision, an Ottumwa newspaper felt steamboats on the river would "induce our businessmen to embark in the packing of pork,

37 Biennial Report of the Board of Public Works of the State of Iowa (Iowa City: Palmer and Paul, State Printers, 1850), p. 16.

38 Ibid.

3o Ibid., p. 6.

${ }^{40}$ Swisher, p. 283.

41 Biennial Report, 1850, p. 41.

42 Ibid., p. 9. 
of which the country even now abounds, and thereby create an export trade of no small extent." ${ }^{33}$ Messrs. Green and Brothers of Bentonsport also went ahead with plans for the expected economic surge. By 1850, they had laid the foundation for a paper mill in anticipation of the completion of the dam. This was hailed as the "first fruit of the Des Moines river improvement." ${ }^{44}$

It soon became apparent that the sale of the land was not proceeding at a rate which could meet the expenses of the work already undertaken. This, coupled with some contractors asking to be let out of their contracts because of flood damage, made it apparent that the Board would have to reorganize the project. ${ }^{45}$ The Board first recommended to the General Assembly the most obvious of alternatives: the issuance of bonds which were to be withheld from the market until prices could be realized from them based upon the "enhancement to be occasioned by the progress of improvement." ${ }^{\text {"46 }}$

Instead of this solution, the Legislature followed the practices of Indiana and Illinois. In similar undertakings, these states had assigned the whole project to private companies when they became bogged down. Accordingly, the Third General Assembly executed a contract with Bangs Bros. and Company of New York to complete the improvements of the river within four years. Compensation was to be the proceeds from the sale of lands below the Raccoon Fork and water rents and tolls below Keosauqua. However, the contract stipulated a minimum sale price for the land of $\$ 2.00$ per acre, while land still belonging to the Federal Government in the even numbered sections could be purchased at $\$ 1.25$ per acre. ${ }^{47}$ Saddled with this impossible burden, Bangs and Company failed within two years.

The project was then sold to another eastern company headed by Henry O'Reilly for $\$ 1,300,000$ and all water

43 Bentonsport Signal, June 21, 1850.

${ }_{44}$ Biennial Report, 1850, p. 41.

45 Swisher, pp. 282-283.

46 Lynn Fleming, "Our Lost Highways," The Plain Talk, May, 1874, p. 75 .

${ }^{47}$ Ibid., p. 76. 
rents, tolls and other sources of income from the improvement for the next 40 years. ${ }^{48}$ The Board hoped to avoid a recurrance of problems and drew a contract that: (a) the new company was to finish improvements from the Mississippi to the Raccoon Fork by July 1, 1858; (b) the new company was to receive all monies due from government and all demands and claims; (c) the new company was to pay salaries of officers and employees of the improvements; (d) the state would convey to the new company the lands at $\$ 1.25$ per acre, as fast as expenditures were made $-24,000$ acres for each $\$ 30,000$ expended; (e) the new company was to pay debts, not exceeding $\$ 60,000$, paying $\$ 55,000$ cash on account; ( $f$ ) the state was to convey lands for expenditures ' $c$ ' and ' $e$ '; (g) state engineers would govern the prices of material and labor where not fixed in the contract; $(h)$ the state Board and its engineers would control the work; (i) the new company was to have the rents and tolls for 75 years instead of 40 , because more lands were sold before the contract than the state or company thought. ${ }^{40}$ By the end of 1853, O'Reilly had organized the Des Moines Navigation and Railroad Company and promised quick results on the river.

The limited progress that Bangs and Company had made was put to use by residents of the Valley. The paper mill at Bentonsport was now in full operation and was the only producer of paper west of the Mississippi. ${ }^{\text {so }}$ Ottumwa now advertised its "abundance of water power" and "several mills and manufacturing establishments." Keosauqua was proud of a "number of schools and churches, several grist and saw mills ... and a number of manufacturing establishments," and a population of 1,200. Bentonsport boasted of being a "flourishing village, with good water power," while further down the river, Bonaparte now had "several grist

48 Roscoe Lokken, Iowa Public Land Disposal (Iowa City: State Historical Society of Iowa), p. 219.

40 Weaver, pp. 426-427.

5o Report of the Commissioner and Register of the Des Moines River Improvement to the Governor of Inwa (Iowa City: Wm. H. Merritt, State Printer, 1852), p. 25. 
and saw mills, and an extensive woollen [sic] factory." One other town in Van Buren County also had "several flouring and saw mills, a foundary [sic], and an engine shop."

Growth of this type was still confined to the southeastern quarter of the state. While the population of Iowa had doubled since 1847, only two more counties could claim over 10,000 residents. Jefferson County was one of these, and it lay in the Valley of the Des Moines. Dubuque County in the northeastern section of the state was the other, while Union County, in southwestern Iowa could still only count 80 settlers. $^{52}$

Promoters of the river improvement saw this rapid growth as justification of the project. Only when complete navigation was possible would the "farmer, the artisan, and every class of men, find a just reward for the enterprise and energy which they may put forth in their various pursuits of life." ${ }^{\text {s3 }}$ Promising a "teeming population," advocates assured the reader that

This is no fancy sketch - no mere idle, glorious picture drawn simply to please the imagination; but THE TRUTH, as the undersigned believe, sincerely and earnestly it will develop itself within less than twenty years from the day when these lines are written. ${ }^{54}$

Many figures and much computation was used to also show skeptics that the arrival of the railway was no threat, for freight rates by water from Keokuk to Ft. Des Moines would still be half the same haul by rail. ${ }^{55}$

Though accused of rampant graft and corruption (and rightly so) the Des Moines Navigation and Railway Company did provide slack water navigation to a point ten miles above Keosauqua. Using cheaper methods than their predecessors, they nevertheless accomplished results. A typical dam consisted of a crib of logs thrown across the river. The crib was then filled with rock and covered with oak plank1855.

51 Mississippi River, n.d., n.p. Printing is after 1846, but before

52 Glass, p. 507.

53 Report of the Commissioner, 1852, p. 25.

54 Ibid.

s5 Ibid., p. 32. 
ing. These constructions lasted for ten years until ice pushed out the rotting weakened timbers. ${ }^{56}$

By the end of 1855 , steamboats were able to reach Keosauqua with no difficulty and Fort Des Moines was accessible much of the period from March to November. Iowa's population had now passed the half million mark, and Van Buren County reported 15,921 to the census. ${ }^{57}$ A great proportion of these new immigrants were going into the interior of the state by water transportation, and Valley newspapers now showed great concern for departures and arrivals and the varying water stages. But 1855 also heard the first knell of the impending death of river navigation. The newly formed Des Moines Valley Railroad began grading a right-of-way from Keokuk to Bentonsport, a distance of 40 miles. ${ }^{58}$ Curiously, this did not dissuade most people. Many likened the river to the Muskingum in Ohio and saw similarities in the location of Pittsburgh and Ft. Des Moines. ${ }^{59}$ How could dreams like these fail?

Thousands of immigrants from St. Louis were now using the Des Moines River as a highway west toward the Pike's Peak region and it was not unusual to "see as many as five steamboats tied up to the landing together" in Keosauqua. ${ }^{60}$ Work continued on the locks and dams with contractors calling for as many as a thousand new laborers at a time. $^{{ }^{11}}$ The river had become "nearly filled with water craft" ${ }^{89}$ and steamboats were even being built on the river. In the summer of 1856, the Des Moines Valley, a "light draught steamer" built especially for this river was launched at St. Francisville on the Missouri side of the Des Moines. ${ }^{83}$

56 Des Moines River, Iowa, Letter, p. 32.

57 Iowa: The Home, p. 13; and House Documents of the Sixth General Assembly of the State of Iowa. Appendix to the Journal of the House of Representatives (Iowa City: P. Moriarty, State Printer, 1857 ), p. 608.

58 Hussey, p. 167.

50 N. Howe Parker, Iowa As it is In 1855; A Gazetteer for Citizens, and a Hand Book for Emmigrants (Chicago: Keen and Lee, 1855), p. 86 .

${ }_{60}$ Des Moines River, Iowa, Letter, p. 22.

61 The Democratic Mirror, (Vernon), June 27, 1856.

${ }^{62}$ Ibid., May 16, 1856.

63 Ibid., June 20, 1856. 
But, by the end of the year the cries of fraud and graft in the Des Moines Navigation and Railroad Company had become too numerous to ignore any longer. The chief engineer was now being paid a salary of $\$ 12,000$ per year and his assistant received only $\$ 2,000$ less. Out-of-state newspapers expected the uncovering of many revelations and sent correspondents to cover the impending investigations. ${ }^{64}$ The fact-finding committee appointed by the General Assembly soon "struck some rich leads." "Old White Coat" (Horace Greeley) of the New York Tribune. He had received $\$ 1,000$ from the Des Moines Valley Navigation and Railway Company for unspecified "aid and comfort" in Washington. ${ }^{66}$

A Van Buren County newspaper warned that "too much confidence should not be placed in an unfavorable report" from the investigation. The committee, the paper alleged, was made up of men who favored applying the river grant of land to the railroads. The paper claimed the only problem to be that work had been too scattered on the river project and that to begin at the mouth and work upstream was the only solution. ${ }^{67}$

The committee brought in its report and recommended that the contract between the State of Iowa and the Des Moines Valley Navigation and Railway Company be terminated, and that the company be paid a reasonable amount for the work they had accomplished ${ }^{68} \mathrm{~A}$ bill was then introduced to this effect, with the comment that had the land "which has been given to this improvement, been appropriated to some railroad company, it might have built a road across the State long before this time."

A month later, the ice went out on the river as far upstream as Bentonsport ${ }^{70}$ and the largest and busiest ship-

${ }^{64}$ H. W. Lathrop, Letters of H. W. Lathrop of Iowa City in 185657, written for the Democratic Press of Chicago, December 22, 1856.

${ }_{65}$ Ibid.

68 Ibid.

${ }^{67}$ The Democratic Mirror, January 16, 1857.

${ }^{68}$ Lathrop, January 23, 1857.

60 Ibid., January $27,1857$.

70 The Democratic Mirror, February 20, 1857. 
ping season, to that time on the river, began. The first boat up the river to Bentonsport was the Kate French, arriving on February 16, ${ }^{71}$ and by the middle of May, 30 steamboats had called at the docks at Bentonsport and Vernon. ${ }^{72}$

June of 1857 saw a new and unwelcome arrival in Van Buren County. Over 4000 tons of rails had been brought up the Mississippi from New Orleans the previous fall and by June 10, 1857, a locomotive could travel from Keokuk to Farmington. By the next spring, the rails reached to Bentonsport. ${ }^{73}$

In March of 1857, the General Assembly could finally see that the importance of the river navigation was decreasing every day as the railroad neared Ft. Des Moines. The Legislature asked the Des Moines Navigation and Railway Company to cease and desist all work in the project and to relinquish claims to all land not yet conveyed to it. At the same time, the legislature threatened to enjoin the company if it did not accept the proposition. ${ }^{74}$ Edwin Manning of Keosauqua, and State Commissioner of the Des Moines River Improvement told the legislature that it was "a melancholy fact that said company claim to have expended half a million dollars, [January, 1858, when three-fourths of the work was to have been completed] and with this immense expenditure claimed by them there is not a single lock or dam completed by them upon the work." ${ }^{.55}$ In reality, the company had done better than Manning claimed, but only slightly. Work accomplished over the six-year period amounted to: (a) a complete engineering survey of the line of the proposed improvement, (b) a ship canal commenced, and a large amount of work performed for a distance of ten miles from the mouth of the river, (c) and three stone masonry locks of a capacity to chamber boats 160 feet long and 44 feet abeam, and two dams were completed. ${ }^{76}$

71 Ibid., February 27, 1857.

72 Ibid., May 15, 1857.

73 Hussey, pp. 168-169.

74 Weaver, p. 428.

75 Fleming, p. 77.

70 Jacob A. Swisher, "The Des Moines River Improvement Project," Iowa Journal of History and Politics, XXXV (April, 1937), p. 164. 


\section{River Enjoys Busiest Season}

It is interesting to note that even while the future of navigation on the Des Moines River hung in the balance, the river was enjoying its busiest season ever. With high water most of the year, over 60 steamboats made the trip to Des Moines, with many others calling at towns below the Fork. ${ }^{77}$ The names of many exist down to the present day: ${ }^{78}$

Hero-89 tons, 116 feet 3 inches long, 17 feet beam, 4 feet 9 inches deep.

\section{Science}

Alice

Agatha

Caleb Cape

Kentucky

J. B. Gordon

Globe

Colonel Morgon

Charles Rodgers-which frequently went as far as Fort Dodge.

Luella

Des Moines Belle-built in Des Moines in 1858.

Skipper

De Moines Valley-built at St. Francisville on the Des Moines River.

Jenny Lind

Badger State

Time and Tide

Clara Hine

Add Hine

Flora Temple-largest craft ever to reach Des Moines.

Nevada

Alex Rodgers

Light

Jeanie Deans-probably the largest boat ever on the river, 485 tons, 236 feet long, $38 \frac{1}{2}$ feet beam, $5 \frac{112}{2}$ feet depth of hold.

Maid of Iowa

G. H. Wilson

N. L. Millburn-built at Iowaville on the Des Moines River.

New Georgetown

Revenue Cutter-sometimes called "Rope Cutter" because her deck hands were prone to cut all ferry ropes stretched across the river that interfered with the progress of the boat.

Ignoring the expanding trade on the river, the General Assembly acceded to the petitions of Polk County (Des

${ }^{77}$ Ibid., p. 407.

78 "River Boats of Early Iowa," Annals of Iowa, XXXIII (January, 1957), p. 539; and Charles R. Tuttle and Daniel S. Durric, An Illistrated History of the State of Iowa (Chicago: Richard S. Peale and Company, 1876), pp. 188-189. 
Moines) to "appropriate the residue of the Des Moines River lands to the construction of the" railroad. Manning, the Improvement Commissioner, was in favor of completing three dams, then under construction, and then concurring in the wishes of Polk County. ${ }^{78}$ By a vote of 21-9 in the Senate and 24-5 in the House, the General Assembly donated the grant to the Keokuk, Fort Des Moines \& Minnesota Railroad Company. The conditions of the grant were that the said company had to assume all liabilities resulting from the Des Moines River improvement operation and that the company had to preserve 50,000 acres of land in security for the payment thereof. Also included in the conditions was the stipulation that the new company would complete and repair dams and locks at Bentonsport, Croton, Keosauqua, and Plymouth. ${ }^{80}$

The new railroad company also found some support from an unexpected source. Because of jealousy, or some other unknown reason, various counties of the state opposed the adoption of the Constitution of 1857 which among other things, established Des Moines as the capital. The people of Des Moines, understandably very interested in the adoption of the Constitution, raised a subscription of $\$ 100,000$ to aid the new railroad company, and gave a majority of 1,500 for ratification of the new Constitution. Lee County (Keokuk), in return for this very high compliment to its pet railroad line, gave a tremendous majority for the Constitution, "and saved the day! But it was a tight squeeze; for the entire state majority was only about $1600 . "{ }^{\prime \prime}$

Van Buren County newspapers continued to concern themselves with river traffic, hoping that perhaps if the railroads were ignored, maybe they would go away. But it was not possible to everyone to ignore the railroad, for the steamer Aunt Letty had her encounter with the Iron Horse. Laden with grain, the Aunt Letty struck a pier on

${ }^{79}$ Keosauqua Republican, February 6, 1858.

${ }^{80}$ The History of Van Buren County. p. 209; and Report of the Commissioner of the Des Moines River Improvement for the Year Past (Des Moines; 1858), pp. 4-5.

81 Hussey, p. 166. 
the new Rock Island bridge and sank to the bottom ${ }^{82}$ Except for minor mishaps such as this, 1859 continued the upward surge of travel on the river. With "plenty of water for the largest boats, ${ }^{\prime 83}$ payloads of 400 tons and 100 passengers $^{84}$ were not uncommon on the river. Capt. F. E. Beers piloted the Charles Rodgers clear to Ft. Dodge, 160 miles above Ft. Des Moines, just to prove it was possible. ${ }^{85}$

The steamboat trade never enjoyed better health as evidenced by two boats, the Des Moines City and the Colonel Morgan, which traveled with bands on board for the enjoyment of passengers. ${ }^{86}$ But some people complained that freight rates were extravagantly high. Careful not to blame the steam companies, a Van Buren County editor held the unfinished dams and locks responsible. He pointed out some dams had been in progress for four to five years; consequently, some locks still remained without gates. This meant that boats had to be windlassed through the resultant race by oxen. "How long," queried the editor, "must this state of things continue." ${ }^{\text {" }}$ However, many people still preferred to travel by boat if at all possible. Vian Buren County delegates to the State Republican Convention were offered half-fare rates toward Des Moines, and the stage line was willing to carry them for two-thirds the usual cost. But the delegates chose to go by steamboat, even though they got hung up on the Skipper at Ottumwa on the return trip and had to complete the journey by stage. ${ }^{88}$

Travel on the river for 1859 ceased on June 28 after a season of 112 days. Total number of arrivals at Keosauqua for this period was 107 vessels. ${ }^{89}$ This year probably marked the zenith of river traffic on the Des Moines. The boating season of 1860 was quite dry and in 1861 many boats were

82 Keosauqua Republicans, March 26, 1859.

83 Ibid., April 16, 1859.

84 Ibid., March 23, 1859.

85 Ibid., April 16, 1859.

86 Ibid., May 28, 1859.

${ }^{87}$ Ibid., April 9, 1859.

88 Ibid., June 25, 1859.

89 Ibid., July 23, 1859. 
transferred to the Mississippi to transport soldiers and supplies. $^{90}$ In March of 1862, the Iowa State Adj. Gen. made arrangements with all boats still operating between Ottumwa and Des Moines to "[carry] to their homes all wounded, disabled or discharged soldiers," for half-fare." Due to an unseasonably wet spring, most roads were impassable in Iowa in March and April of 1862. Many members of the General Assembly and their attaches had to proceed home by steamer. At least 87 embarked down the river on the De Moine Belle, some going clear to Keokuk, then up the Mississippi to their homes as far away as Dubuque. ${ }^{92}$

When the war was over, few wanted to continue the pretense of profitable navigation on the Des Moines River. Newspapers now printed railroad schedules instead of steamboat arrivals and departures. ${ }^{33}$ The rails had finally reached Des Moines in August of 1866 and other companies were spanning the state $^{.4}$ The Rock Island, which began construction in 1855, reached the Missouri in 1861. The Burlington line began one year earlier and reached the western border 1870. Both the Milwaukee and Illinois Central began their building in 1870 and had crossed the state eleven years later. The Northwestern offered service to Cedar Rapids by 1859 and to Council Bluffs by $1867 .^{95}$ These lines could offer service and reach cities never dreamed of by the steamboat companies.

Charles Dudley, a state representative from Wapello County (Ottumwa), introduced the following resolution in January of 1866 .

Whereas, By the facilities that are afforded by the D.V.R.R., for travel and transportation, the Des Moines River is no longer used for purposes of navigation...

Reserved therefore ... that our Senators and Representatives in Congress be requested to use there [sic] influence to have the said Des Moines River declared not a navigable

90 Gustav Larson, "Notes of the Navigation of Iowa Rivers," Iowa

Journal of History and Politics, XXXIX (October, 1941), p. 408.
1
Hussey, p. 123 .

92 Ibid., p. 124.

93 Bentonsport Signal, March 20, 1867.

04 Hussey, p. 171.

05 Weaver, p. 427. 
stream, to the end that the same may be more cheaply improved as a motive power for machinery. ${ }^{96}$

By the end of the month the Senate had concurred. ${ }^{97}$ It was not until 1870 however, that Senator Harlan asked for approval of the above memorial in the United States Senate. $^{98}$ By Feb. 1, 1870, the memorial became law and the Act of 1846 which declared the Des Moines River a public highway was repealed. ${ }^{99}$ The approach of railroads, the improvement of roads, and the demand for the steamers on the lower Mississippi during the Civil War made business unprofitable at best. One of the obituaries, years later ran thusly:

This act, of all congressional grants of lands, was one of the best calculated to be of general benefit. The management and history of the grant have made it perhaps the most ineffective and the most injurious of all. Instead of bettering the navigation of the river, the grant was so administered as actually to destroy it. ${ }^{100}$

Hopes which had been raised so high just a few years before now had to turn from the river to new avenues of transportation. Where once the man looked down the river for a tell-tale wisp of smoke that signaled the arrival of a steamboat, now he looked down the right-of-way, or consulted the rail schedules in the newspaper.

${ }^{96}$ Journal of the House of Representatives of the Eleventh General Assembly of the State of lowa (Des Moines: F. W. Palmer, State Printer, 1866), p. 88; and Acts and Resolutions Passed at the Regular Session of the Eleventh General Assembly of the State of Iowa (Des Moines: F. W. Palmar, State Printer, 1866), pp. 182-183.

${ }_{97}$ Journal of the Senate of the Eleventh General Assembly of the State of Iowa (Des Moines: F. W. Palmar, State Printer, 1866); p. 163.

${ }^{88}$ The Congressional Globe, 2nd Session, 41st Cong., Vol. XLII, No. 1, p. 411.

99 Appendix to the Congressional Globe, p. 634.

100 Fleming, pp. 73-74.

\section{BOOK REVIEWS}

The 1966 Johnson volume of the Public Papers of the Presidents of the United States is now on sale through the Superintendent of Documents, Government Printing Office, Washington, D. C. 20402. This volume, which contains 
Copyright of Annals of Iowa is the property of State of Iowa, by \& through the State Historical Society of Iowa and its content may not be copied or emailed to multiple sites or posted to a listserv without the copyright holder's express written permission. However, users may print, download, or email articles for individual use. 